Tomasz Je $\dot{z}$

Institute of Musicology

University of Warsaw

\title{
From a Musical Humanist's Diaries. The Schreibkalenders of Elias Maior (1588-1669) as a Source for the History of Wrocław Musical Culture
}

The object of this article is the contents of the notes of Elias Maior, a rector of St. Elizabeth's gymnasium in Wrocław, made in the consecutive 1640-1669 Schreibkalenders. They constitute a rich source documenting everyday life of Wrocław's humanistic elite. Of particular interest, among the rector's accounts, are numerous references to music performed, both in public and in private domain.

Keyw o rds: Wrocław, humanism, reformation, St. Elizabeth's gymnasium, Elias Maior

A school, established next to the St. Elizabeth's Church in Wrocław, was one of the most important centres of humanism in Silesia since mid-fifteenth century, ${ }^{1}$ due to the activity of Wrocław erudites, maintaining regular scientific contacts with such renowned humanists as: Gianfrancesco Poggio Bracciolini, Enea Silvio Piccolomini, Lorenzo Valla or Conrad Celtes (Conradus Celtis, Konrad Bickel). Hierarchs of the Wrocław bishopric curia and teachers of Wrocław schools,

${ }^{1}$ G. Bauch, Geschichte des Breslauer Schulwesens vor der Zeit der Reformation (Breslau, 1911; Codex diplomaticus Silesiae, vol. 26), pp. 200-239. 
often alumni of the Cracow Academy, ${ }^{2}$ used to be their correspondents and students. A particular role in this milieu was played by Laurentius Corvinus (Laurenz Rabe), who 1497-1502 was governing the St. Elizabeth's school in Wrocław and gave a distinctly humanist profile to its curriculum. ${ }^{3}$ This earning program consisted of, i.a., a complete Latin course, lecture of ancient authors and also a school theatre, initiated by performances of comedies by Terence and Plautus. Corvinus's humanist worldview was rooted in Neoplatonic ideas, which justified not only the universalism of the literary tradition actively maintained by him, but also its reference to the concept of harmony of the celestial spheres, ${ }^{4}$ Christian moral values ${ }^{5}$ and religious experiences, revealed in an original adaptation of St. Bonaventure's works, created for a Liturgy of the Passion at the Wrocław Parish Church. ${ }^{6}$

Most probably, it was Corvinus who was the true addressee of Philip Melanchthon's letter, dated 19 February 1521,7 in which the praeceptor Germaniae sent words of praise for the teaching curriculum, bringing it to the attention of the next headmaster of the Elizabethan school Johannes Troger. Besides, the pedagogical concept linking humanist education to religious formation and civic upbringing, perfectly fitted the vision of Melanchthon, who was also a tutor and promoter of a couple of generations of Wroctaw pastors and teachers. ${ }^{8}$ The specific

2 See idem, "Beiträge zur Literaturgeschichte des schlesischen Humanismus," Zeitschrift des Vereins für Geschichte und Altherthum Schlesiens 30 (1896), pp. 127-164.

3 See idem, "Laurentius Corvinus, der Breslauer Stadtschreiber und Humanist," Zeitschrift des Vereins für Geschichte und Althertum Schlesiens 17 (1883), pp. 230-302.

${ }^{4}$ Carmen elegiacum Magistri Laurentij Coruini... De Apolline et nouem Musis (Breslau, 1503; copy Cracow, Jagiellonian Library [Biblioteka Jagiellońska, hereafter: BJ], St. Dr. Cim. 5151).

${ }^{5}$ Dialogus... de mentis saluberrima persuasione... (Lipsiae, 1516; copy Wrocław, University Library [Biblioteka Uniwersytecka, hereafter: BUWr], 462103).

${ }^{6}$ Cursus Sancti Bonaventurae de passione domini cum invitatorio himnis et canticis Laurentij Corvini (Breslau, 1521; copy Cracow, Scientific Library of the Polish Academy of Learning and the Polish Academy of Sciences [Biblioteka Naukowa Polskiej Akademii Umiejętności i Polskiej Akademii Nauk], sign. Cim. 80 I. G).

7 Philippi Melanchthonis opera quae supersunt omnia, ed. C.G. Bretschneider (Halle, 1834; Corpus Reformatorum, vol. 1), p. 283; Bauch, Geschichte des Breslauer Schulwesens, p. 39.

${ }^{8}$ Ch. Absmeier, "Szkoły a region: szkolnictwo śląskie wieku reformacji," in: Śląsa Republika Uczonych, vol. 3, ed. M. Hałub, A. Mańko-Matysiak (Wrocław, 2008), pp. 121-132, here p. 123. 
conciliatory nature of Silesian Protestantism, activists of which introduced the first reforms in a gradual and far more compromise way than anywhere else, is considered to be a fruit of his efforts. ${ }^{9}$ The successive changes in the liturgical order in Wrocław churches ${ }^{10}$ were accompanied by modifications of the curricula in its schools; while the key player for these changes was the municipal authorities that supervised educational procedures in schools, sent their graduates to universities and, subsequently, required from them to take a job in the hometown. ${ }^{11}$ The result of this perfectly organised institutional symbiosis was the increasing independence of the town's elite and the ability to effectively oppose the growing Habsburg influence and the Counter-Reformation.

Until the 1580s, the Philippian humanism constituted the ideological profile of the Silesian Lutheranism. Later, its conciliatory nature was gradually taken over by more radical formula, which finally came to the fore during the Thirty Years' War. ${ }^{12}$ Did the humanist irenism, planted in Wrocław's elite by Melanchthon, definitely surrender to a far more radical Luther's vision and the so-called Lutheran Orthodoxy, derived from it, which in mid-seventeenth century became the dominant narrative, even in Silesia? We will search for an answer to this question in a unique document of the era - the diaries of Elias Maior, a long-time rector of the Elizabethan gymnasium..$^{13}$ But before we will take a closer look at the picture of everyday life, given by this teacher and humanist, let's see how this life was organised in previous years.

9 See J. Harasimowicz, "Śląski luteranizm wieku Reformacji - próba charakterystyki," Ślaski Kwartalnik Historyczny Sobótka 39, no. 4 (1984), pp. 493-516.

${ }^{10}$ Described in detail by H.-A. Sander, Beiträge zur Geschichte des Lutherischen Gottesdienstes und der Kirchenmusik in Breslau. Die lateinische Haupt-und Nebengottesdienste im 16. und 17. Jahrhundert (Breslau, 1937), passim.

11 See T. Jeż, "Stypendia wrocławskiej Rady Miejskiej jako instytucja kształcenia kadr muzycznych," in: Śląsa Republika Uczonych, vol. 3, ed. M. Hałub, A. Mańko-Matysiak (Wrocław, 2008), pp. 155-181.

12 M.P. Fleischer, "Die Konkordienformel in Schlesien," Jahrbuch für schlesische Kirchengeschichte 58 (1979), pp. 52-54; Harasimowicz, op. cit., p. 497.

13 J.C. Arletius, Historischer Entwurf von den Verdiensten der Evangelischen Gymnasiorum in Breslau um die deutsche Schaubühne (Breslau, 1762), p. 42; M. Hippe, "Aus dem Tagebuche eines Breslauer Schulmannes im siebzehhnten Jahrhundert," in: Breslauer Studien. Festschrift des Vereins fur Geschichte und Althertum Schlesiens zum fünfundzwanzigjährigen Amtsjubiläum seines Vizepräses Hermann Markgraf (Breslau, 1901), pp. 159-192. 
Ambrosius Moiban (Moibanus; 1494-1554) must be regarded a key figure. After studying in Cracow and Vienna, he published a selection of hymns by Giovanni Pico della Mirandola and of Erasmus's epistles, and, in 1520, he came to Wittenberg, where he was taught by Melanchthon and Luther. His education was crowned by the appointment, in 1525, to the post of St. Elizabeth's Church parish pastor. ${ }^{14}$ The reorganisation of liturgy was accompanied by a regulation of the didactics at schools, conducted by the subsequent headmasters. ${ }^{15}$ In the very way the reforms were introduced one can see Melanchthon's approach: according to, e.g., the 1528 Schulordnung by Moiban, the school's curriculum should focus on original sources for the Bible and encompass grammar classes and a musical practice. ${ }^{16}$ By Melanchthon's inspiration, Latin declamations, which served as exercises in Latin for the pupils and as an aid in learning the particularities of human nature, were also in the program of the Wroclaw school. ${ }^{17}$ To realise this program, Moiban's publications were also used, encompassing, i.a., a Latin grammar textbook, printed back in Leipzig, ${ }^{18}$ a frequently reprinted catechism with Melanchthon's preface $^{19}$, and an edition of comedies by Terence with Melanchthon's commentaries and a preface by Moiban. ${ }^{20}$

The last two positions were printed by Andreas Winkler (14981575), who, since 1526, was a headmaster of St. Elizabeth's school. ${ }^{21}$

${ }^{14}$ J. Soffner, Geschichte der Reformation in Schlesien (Breslau, 1886), pp. 41-46; P. Konrad, Die Einführung der Reformation in Breslau (Breslau, 1917), pp. 65-67.

15 The forming process of the school curriculum in Wrocław Protestant gymnasia is presented by J. Budzyński, Paideia humanistyczna czyli wychowanie do kultury: studium z dziejów klasycznej edukacji w gimnazjach XVI-XVIII wieku (na przyktadzie Ślaska) (Częstochowa, 2003), pp. 61-67, 96-105, 140-145.

16 J. Sass, Die kirchenmusikalischen Ämter und Einrichtungen an den drei evangelischen Haupt- und Pfarrkirchen der Stadt Breslau (Breslau, 1922), pp. 27-28, 41-42.

17 Compare Melanchthon's letter dated 17 April 1520 to Johannes Hess, a pastor of Wrocław St. Mary Magdalene’s Church, in: Philippi Melanchthonis opera, vol. 1, p. 135.

18 Pedia artis grammaticae Ambrofii Moibani... Adiectus est libellus Eras[mi] Rote[rodami] de conftructione... (Lipsiae, 1522; copy BUWr, sign. 442131).

${ }^{19}$ Catechismi capita decem, primum quibufdam thematis, Deinde etiam Colloquiis puerilibus illuftrata, iuuentuti Vuratislauienfi proposita... (Vitebergae, 1538; copy BUWr, sign. 301174).

${ }^{20}$ P. Terentii Comoediae... Accesservnt praeter argumenta Philippi Melanch. ... (Breslau, 1540; copy BUWr, sign. 304514).

${ }^{21}$ See M. Burbianka, "Andrzej Winkler - drukarz wrocławski XVI wieku," Roczniki Biblioteczne 4 (1960), pp. 329-445, 636-638. 
He also studied in Cracow and Wittenberg, where he obtained a Master's degree under Melanchthon's supervision; moreover, his promoter delivered on this occasion a laudation (which was also printed). It was Winkler who subordinated his school to the administration and budget of the municipal authorities. He systematically sought to convert the school into a higher education institution, the first step towards which was the granting it the status of a gymnasium in 1562. As the first rector of the Elisabetanum, Winkler developed its curriculum, increasing the number of classes from three to five. Aided by Melanchthon's instructions, he also enriched the reading list with further Latin and Greek authors and dialectical, rhetorical and theological works. He published them in a printing office, established by him in 1538, enjoying privilege of the municipal authorities (and later even of the Emperor himself!) to publish schoolbooks. On his list of publications, there are Cicero's epistles, Horatio's odes, Aristotle's and St. Augustine's writings, Melanchthon's epigrams, the above-mentioned Terence's comedies and Moiban's works, and also a treatise on music theory. ${ }^{22}$

Winkler's school reforms were continued by his successor, Petrus Vincentius (Peter Vietz; 1519-1581), another student of Luther and Melanchthon, who after graduation worked as a teacher in Lübeck, Wittenberg and Görlitz and, in 1569, returned to his home city, Wrocław. Not long after taking posts of the rector at the Elisabetanum and school inspector, he published, in 1570, a new School order (Der Stadt Breslaw Schul-Ordnung), basing it on Winkler's reforms already in vigour. Among others, he introduced a 5-year education cycle at the gymnasium and established reading lists for each class. ${ }^{23}$ They included works of Cicero, Plautus, Ovid, Terence, Virgil, when it comes to the Latin literature. As for Greek, there were works of Demosthenes, Hesiod, Homer, the Gospels and St. Paul's epistles, and, furthermore, dialectical, rhetorical and theological texts (based on Melanchthon's Examen theologicum), and selected books of the Bible (studied in original languages). The theological lectures took place in the Auditorium theologicum, placed over the sacristy of St. Elizabeth's Church, which greatly emphasised the relationship between the school and the parish. ${ }^{24}$ Humanist horizons of Wroctaw rector are

${ }^{22}$ Erotemata Mvsicae Practicae ad captum puerilem formata, Virgilio Haug autore... (Vratislaviæ, 1541; copy BUWr, sign. 380605).

${ }^{23}$ Budzyński, Paideia humanistyczna, pp. 131-135.

${ }^{24}$ K. Garber, Das Alte Breslau. Kulturgeschichte einer geistigen Metropole (Köln, Weimar, and Wien, 2014), p. 135. 
also confirmed by his publications, i.a. of Plautus's comedies, Erasmus's treatises or Melanchthon's epigrams. ${ }^{25}$

Vincentius's successors cared about this wide-scale humanist education: Nikolaus Steinberg (Steinbergius; held the Elisabetanum rector's office in 1578-1610), Petrus Kirstenius (Peter Kirstein; 1610-1616), and, especially, Thomas Sagittarius (Schütz; 1616-1621), an author of numerous publications, honoured with the title of poeta laureatus. ${ }^{26}$ However, at their times, the fateful confrontations of Silesian Protestantism fell with the increasing re-Catholising tendencies and also with the theological trend that was leaning toward Calvinism, more and more popular among the successors of Melanchthon's thought. ${ }^{27}$ These movements, on the one hand, resulted in the definite breaking of the relation with Catholicism, but on the other - they contributed to the consolidation of Protestantism that, henceforth, was focused rather on Luther's than on Melanchthon's thought. The followers of Philipism were deprived (as crypto-Calvinists) of teaching and pastoral posts, while the theologians appointed to them were obliged to be loyal to Lutheran Orthodoxy. This type of declarations made by Steinberg, Kirstenius and Sagittarius, ${ }^{28}$ did not, however, prevent them from keeping alive the philological tradition, implemented in Wrocław elite through Melanchthon, cultivated by its representatives in educational institutions of the city.

The key role was played here by Elias Maior (Major; Grosser), who was appointed to the post of the Elisabetanum's rector after Michael Pollius (Pol; 1621-1631) and held it during the following 38 years. Maior was born in Wrocław on 26 February 1588 as a son of Elias Grosser, a shoemaker. Most probably, he was educated at St. Elizabeth's gymnasium, since he mentioned Steinberg and Kirstenius as excellent tutors and erudites. ${ }^{29}$ In April 1610, he received a scholarship from the municipal authorities (of 57 thalers a year) to study theology in Wittenberg. A year later, the scholarship was renewed and paid until $1615 .{ }^{30}$

${ }^{25}$ Burbianka, op. cit., p. 416.

26 J.L. Flood, Poets Laureate in the Holy Roman Empire, vol. 4: S-Z (Berlin, 2006), pp. $1794 \mathrm{f}$.

27 Harasimowicz, op. cit., pp. 503-505.

${ }_{28}$ Bauch, Geschichte des Breslauer Schulwesens, pp. 241-242.

${ }^{29}$ J.H. Cunradus, Silesia Togata, ed. C.Th. Schindlerus (Lignicii, 1706), p. 181; Bauch, Geschichte des Breslauer Schulwesens, pp. 318, 339.

30 Wrocław, State Archives (Archiwum Państwowe, hereafter: APWr), "Akta miasta Wrocławia," zespół 28, 3944 (olim: P 31), "Stipendiaten-Rechnungsbuch," fol. 128ver.-129rec. 


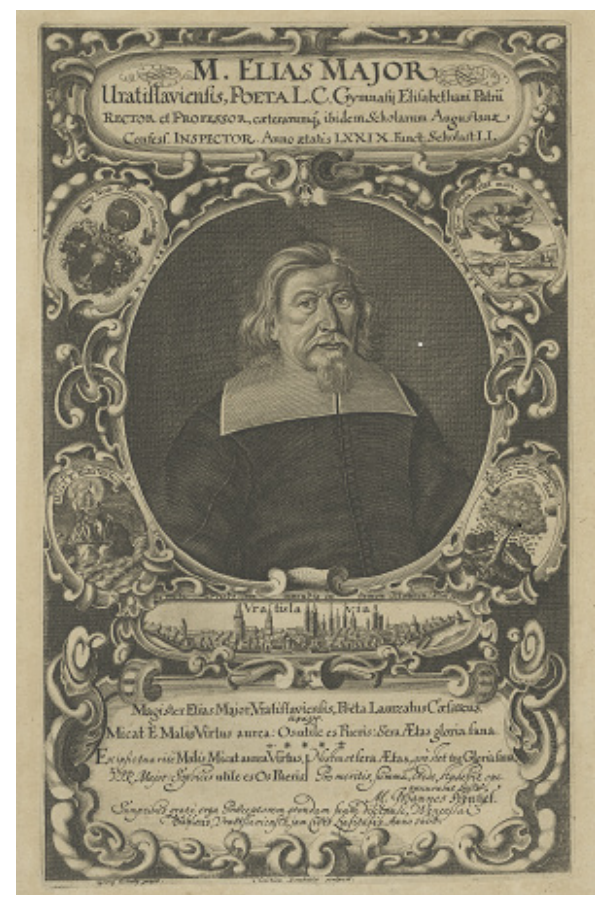

Fig. 1. Elias Maior, engraving by Christian Romstet, 1667

(Universitätsbibliothek Leipzig, Porträtstichsammlung, Inv.-Nr. 31/56)

Apart from studying theology and philosophy, Maior committed himself to Wittenberg's musical life; together with other Silesian students, he also founded a Collegium declamatorium privatum (its members were staging a play on a weekly basis). ${ }^{31}$ After obtaining the Master's degree, as stated in his scholarship agreement, Maior put himself at Wrocław municipal authorities' disposal. On 18 March 1615, he was appointed a Collega tertii ordinis at the Elisabetanum, ${ }^{32}$ and a couple of months later he also took up duties as a music teacher. ${ }^{33}$ From 1617, he was recorded as Collega primi ordinis and Professor historiarum et oratoriae.

${ }^{31}$ Hippe, op. cit., p. 160.

${ }^{32}$ M. Hancke, Vratislaviensis Eruditiones Propagatores: Id est, Vratislaviensium Scholarum Presides, Inspectores, Rectores, Professores, Praeceptores Tabulis Chronologicis comprehensi (Leipzig, 1701), p. 23.

33 APWr, "Akta miasta Wrocławia," zespół 28, 3944, fol. 129rec.: “ist am 1615 Junii S. Elisabeth in locum cantoris in schola sustineret." Cf. Jeż, "Stypendia," p. 170. 
Elias Maior's intellectual qualifications are emphatically confirmed by the poeta laureatus title, bestowed on him on 1 May 1631,34 and a next week appointment to the post of rector of St. Elizabeth's gymnasium. ${ }^{35} \mathrm{He}$ held this post until his death on 17 July 1669. In private life, Maior was, from 1618, married to Maria Profe, a daughter of a Wrocław clothmaker, Daniel, and a sister of Ambrosius (15891661), a fellow student, known to Elias from their times at Wittenberg, who was later active (in 1633-1649) as an organist of St. Elizabeth's Church in Wrocław. ${ }^{36}$ Maria and Elias had eight children, but we have information only about the couple's three sons: the oldest, Esaias, worked as a lawyer in Jauer (Jawor), Elias jr. was a pro-rector of a school in Oels (Oleśnica) and later a teacher at the Elisabetanum, whereas Johann Daniel was a professor of medicine at the Kiel University. ${ }^{37}$ Contrary to his sons, Elias Maior spent almost all his life in Wrocław, devoting time, mainly, to the St. Elizabeth's gymnasium led by him. As, at the same time, he was appointed to the position of the school inspector by Wroctaw municipal authorities, he supervised educating procedures at other schools in the town, especially at St. Mary Magdalene's school, which, in 1643, was given a gymnasium status and, i.a., thanks to Maior, received its own Schulordnung the same year. ${ }^{38}$

The profile of Wrocław Elisabetanum's rector is brought closer by his publications, mostly associated with his teaching activity. His epigrams, ${ }^{39}$ poems on philosophical, occasional and moral subjects, ${ }^{40}$ paraphrases of the Psalms ${ }^{41}$ and religious poetry, mostly on the Pas-

${ }^{34}$ J.L. Flood, Poets Laureate in the Holy Roman Empire, vol. 3: L-R (Berlin, 2006), pp. 1233-1237; Garber, op. cit., p. 153.

35 Hancke, op. cit., p. 28.

36 R. Starke, “Ambrosius Profe," Monatshefte für Musikgeschichte 34, no. 11 (1902), pp. 189-196; 34, no. 12 (1902), pp. 199-215.

37 Hippe, op. cit., p. 161.

38 Budzyński, Paideia humanistyczna, pp. 140-141.

${ }^{39}$ M. Eliae Majoris anagrammatum semicenturia... (Vratislaviæ, [1634]; copy Warsaw, National Library [Biblioteka Narodowa, hereafter: BN], sign. SD XVII.3.16748); Epigrammata quaedam miscella... (Vratislaviæ, [1641]; copy BN, sign. SD XVII.3.17021); Primitice Epigrammatum Magnificis Munificisq[ae] Patronis... (Breslæ, [1645]; copy BUWr, sign. 445373).

${ }^{40}$ M. Eliae Majoris L. Parodice, ad illud, Omnia fi perdas \&oc. ... (Vratislaviæ, [after 1636]; copy BUWr, sign. 354954).

${ }^{41}$ M. Eliae Maioris Vratislaviensis Psalmus Davidicus unus \& nonagesimus, Rysiou instar, pro divina, contagioso tempore protectione (Vratislaviæ, 1626; copy BUWr, sign. 354957); Psalmus Davidis CIII.: Carmine Heroico Expressus Deo Protectori, 
sion, have also been preserved. ${ }^{42}$ The largest group of printed matter by far, signed by Maior, consists of the programmes of the school declamations staged by the pupils of his gymnasium. ${ }^{43}$ They are versed Latin and German exercitia scholastica on historical, ${ }^{44}$ political, ${ }^{45}$ biblical, ${ }^{46}$ religious ${ }^{47}$ and occasional subjects, ${ }^{48}$ i.a., on the centenary

Consolatori, Liberatori Opt. Max. Sacrum Esse Voleb. Voti Damnas M. Elias Major (Vratislaviæ, 1629; copy BUWr, sign. 354958); Psalmus Davidicus Centesimus Septimus: Hexametro Carmine expressus \& Deo Custodi atq[ue] Opitulatori consecratus a M. Elia Majore Vratisl. P.L.C. (Vratislaviæ, 1634; copy BUWr, sign. 354959).

42 Die Sieben Georgii Fabricii, auß des H. Christi Sieben Worten am Creutze abgefaste Andachten... au $\beta$ dem Latein ins Deutsche versetzt von M. Elia Maiore (Breßlaw, 1646; copy BUWr, sign. 354943); Das Leyden unseres Hej̈landes: auß dem Lateinischen Johannis Claji ubergefetzt, mit Dreyen darzu gefügten Leidens-Andachten von M. Elia Majore (Breßlaw, [1650]; copy Berlin, Staatsbibliothek Preußischer Kulturbesitz [hereafter: Berlin], sign. Yi 2766).

${ }^{43}$ Cf. Budzyński, Paideia humanistyczna, pp. 405, 407, 416, 417.

${ }^{44}$ Dissertatiunculas de Urbe Roma deque Regibus Romanis, cum quibusdam Synchronifmis a. d. XXX. Julii Ann. Chrift. M DC XLVIII. in Gymnafio Vratislavienfi Elifabetano habendas... (Vratislaviæ, 1648; copy Berlin, sign. Ah 16124/8); De Carolo Quarto Rom. Imperatore \& Bohem. Rege Urbis Vratislavia... amplificatore, exercitiis nonnullis juvenilibus mentionem facularem in Gymnafio Vratislavienfium Elifabetano... faciendam indicit M. Elias Major, laudati Gymnafii Rector (Vratislaviæ, 1653; copy Berlin, sign. Ah 16124/27); Ex Q. Curtii Libri tertii capitibus fex primis Oratiunculas In Gymnafio Elifabetano A.D. VI. Non. Majas ann. Chr. CID IDC LVIII habendas, indicit M. Elias Major, Gymnafii Rector (Vratislaviæ, 1648; copy Berlin, sign. Ah 16124/34).

${ }^{45}$ Dissertationes scholasticas et Politicorum Inftitutionibus De abfolutè Imperantium Poteftate, atque Majeftate... indicit Elias Major (Vratislaviæ, 1652; copy Berlin, sign. Ah 16124/24).

${ }^{46}$ Quod bene vertat! Execitatia scholastica altera ex historia Jonae \& Ninivitarum, itemq[ue] ex Hymno Josaphati, a.d. 18. Decembr. Ann. 1642. in Elisabetano Gymnasio, habenda indicit M. Elias Major Rector (Breslae, 1642; copy BUWr, sign. 539011).

47 Sacra quaedam exercitia de angelis a.d. Prid. Non. Octobr. ann Chr. CID IDC XXXIX in Gymnasio Vratislaviensi recitanda indicit M. Elias Major, rector (Vratislaviæ, [1639]; copy BN, sign. SD XVII.3.4953 adl.); Soteria in Gymnasio Vratislaviensi A.D. IV Cal. April. Ann. Christ. CID IDC XLIX Celebranda Indicunt M. Elias Major Rector, \& Christophorus Colerus Conrector (Vratislaviæ, [1641]; copy Berlin, sign. Ah 16124/1); Meditationes passionales ex psalmo XXII potissimum susceptas an. Chr. CID IDC XLII a.d. XIV Cal. Majas horis a prima pomeridianis in Gymnasio Vratislaviensi recitandas indicit M. Elias Major (Breslæ, [1642]; copy BN, sign. SD XVII.3.4966 adl.).

${ }^{48}$ Exercitium Poëticum Vota Pro Felici Novo Anno complexum, A.D. XIX. \& XVIII. Calend. Febr. publice habendum indicit M. Elias Maior Vratislavienfis Hiftor, 
of Philip Melanchthon's death. ${ }^{49}$ Some of these performances were based on texts by ancient authors: Horace, Seneca and Cicero, ${ }^{50}$ that belonged to the canon of readings of the Wrocław gymnasium. Traces of Maior's didactic activity are also a small Latin dictionary edited by him, ${ }^{51}$ his school speeches ${ }^{52}$, and a grammar textbook, published posthumously. ${ }^{53}$ Maior's active presence in the life of Wrocław elite is also confirmed by his occasional poetry. We can find is poems in collections of works by many authors: epithalamia ${ }^{54}$ dedicated to newly-weds, congratulations for acquaintances on name days or birthdays ${ }^{55}$, or epitaphs, in memory of the deceased. ${ }^{56}$

Profeffor (Vratislaviæ, 1625; copy Berlin, sign. Xc 567/41); Exercitia scholastica de oleâ, pietatis novo anno rite inchoando... in Gymnasio Elifabetano habenda... (Vratislaviæ, 1649; copy Berlin, sign. Ah 16124/12).

49 Sacularem Melanchthoniani Diei Emortualis, memoriam in Gymnafio Vratislavienfi Elifabetano a.d. IV. Non. Majas Anni Chr. CID IDC LX... recolendam indicit M. Elias Major Rector (Vratislaviæ, 1660; copy BUWr, sign. 444378).

${ }^{50}$ L. Annai Seneca De Providentia Caput Terrium Pro Nundinali Lectione defcribi curabat M. Elias Major... (Vratislaviæ, 1648; copy BUWr, sign. 444335); Romanum de capite Horatii judicium liberalis exercitionis causa ex Junianis orationibus lingva Germanica in Gymnasui Elisabetano... indicit M. Elias Major (Vratislaviæ, [1649]; copy BN, sign. SD XVII.3.4962 adl.); De M. Tullio Cicerone, ante ipfa facula decem \& feptem interemto, ex Plutarchi potisfimum historiâ exercitia scholastica... in Gymnafio Elifabetano... recitanda (Vratislaviæ, 1658; copy Berlin, sign. Ah 16124/37).

${ }^{51}$ Dictionarium nominum verborumque secundum accidentia Grammatices Latine digestorum... (Breslau, 1620; copy BJ, sign. 19809-I).

${ }^{52}$ M. Elia Maioris Orationes Tres In Gymnasio Vratislaviensi Habite (Lipsiæ, 1626; copy BN, sign. SD XVII.1.955).

${ }^{53}$ M. Elia Majoris Vratislaviensis... Liber Postumvs De Varianda Oratione, Ad Lectionem Veterum, Et Sermonis Puri Copiam Parandam In Primis Necessarius... (Vratislaviæ, 1684; copy Berlin, sign. Wa 1390).

${ }^{54}$ Viro Quâ dignitatem, Venerabili... Johanni Tralles, Pastori Ecclefie Hirschbergensis... Sponso..., cum Catharina, Dn. Georgi VVolfgruberi fenatoris Reipubl. eiufdem... Filia... ([Wrocław], 1620; copy Berlin, sign. Xc 573/45); Felicitatem Conjugalem Viro Reverendo... Dn. M. Abrahamo, Andrea F. Eccardo, Ecclefia Namflaviensis Diacono Fidelifsimo: Virginum... Annam... Dn. Pauli Neandri, Advocatia, que Vratislavia eft... Filiam, ... in matrimonium ducenti... (Vratislaviæ, 1645; copy Berlin, sign. Yf 6807/24); Honeftisimis Sponfis, Eruditissimo Viro, M. Johanni Balthasari Cargio, In Elifabethano \& Barbarino Templo apud Vratislavienfes chori Mufici Prafecto, \& in Gymnafio, quod illi vicinum est Adi, Collega bene merenti, atque... Virgini, Elisabeta... Georgii Weirauchii... Filia Unica, Matrimonium... (Vratislaviæ, 1665; copy Berlin, sign. Yf 6807/65).

55 In Hoffmanniana Nominalia... Anni CID IDC XXXIII extremi, Duo M.E.M. Poёmata... (Vratislaviæ, [1633]; copy BUWr, sign. 440068); Nobilis, Clarisimi, Confultifsimiq; Viri Dn. Thome Schrcerijcti... Onomasteria... M. Elia Majore 
Elias Maior was himself an addressee of analogous poetry: epigrams created on the occasion of laureating him, ${ }^{57}$ name day and birthday congratulations ${ }^{58}$ or nenias crowning his life. ${ }^{59}$ If we consider this specific mixture of official narration with the discourse of Wrocław teacher's private life to be a somewhat humanist feature, a similar profile is revealed in his Schreibkalenders, written during the consecutive decades of his life. These sources allow us to capture Elias Maior's figure more vividly and to interpret more fully his literary and didactic oeuvre. These notes are also a reach and colourful documentation of everyday existence of the Elizabethan gymnasium's rector that took place both in publicis: at school, in church and town's hall, and privatim: at friends' houses, gardens and taverns. We will present here the emerging picture only in one of the possible perspectives, related to the soundscape of the metropolis on the Oder, described by Maior. However, we hope that this perspective,

P.L.C. (Breslæ, [1641]; copy BUWr, sign. 442792). Elias Maior's contacts with Christian Hoffmann von Hoffmannswaldau - his pupil at the Elisabetanum, and later a distinguished poet of the Silesian baroque, who was the addressee of the dedication of the first poem mentioned here, - has already been written about by L. Noack, Christian Hoffmann von Hoffmannswaldau (1616-1679): Leben und Werk (Tübingen, 1999), pp. 54-55, 146-147, 151, 208, 220, 231, 308, 320, 379.

${ }^{56}$ Epitaphium Anne Closie, Virginis... Florentissime; Ejusdem Parenti... M. Henrico Closio, Gymnafii Magdalenæi Vratislavienfis Rectori... confolaitonis ergo exhibitum a M. Elias Majore, P.L.C. Gymnafii Vratislavienfis Elifabetani Rectore... ([Wrocław, after 1644]; copy BUWr, sign. 412691); Erimiis Virtutibus... Johannis ab Haunoldt... Ann. 1655... consecrate a Clientibus Epicedia (Vratislaviæ, [1655]; copy BUWr, sign. 443956); ПАPAM $\Theta I A$, Viro Nobilissimo... Domino Godofredo Wolffio, J.U. Licent. Illustriss. Comitis ab Hazfeld, \& Gleichen, Liberi Baronis in Wildenberg \& Trachenberg, Consiliario longe dignisimo, lugenti Obitum promaturum Filii dilectiesimi, Adolescentuli Godofredi Wolffi... (Vratislaviæ, 1660; copy Berlin, sign. Xc 577/39).

${ }^{57}$ Elia Maioris Vratislaviensis Ann. Chr. M.DC.XXXI Calendis Majis, Laurea Casarea Poetica solemniter redimiti, \& VIII. Idus Majas Rectoris Gymnasii Vratislaviensis, publice \& legitime renunciati, Adorea partim Utraque, partim Alterutra, Fautorum, Amicorum, Discipulorum, Gratulationibus, omnibus, votis, ornate... (Vratislaviæ, [1631]; copy London, British Library, sign. 11409.bb 50).

${ }^{58}$ Muпnosvvov Natali Quarto \& Sexagefimo... Dn. M. Elia Majoris. P.L.C. Gymnasii Elifabetani... dedicatum à Filio \& ejus quibufdam amantifsimis Dijcipulis (Vratislaviæ, 1651; copy BUWr, sign. 444288).

${ }^{59}$ Decus et Gloriam Musarum Vratislaviensium, Hoc est, Nobilem, Excellentissimum, Clarissimumque Virum M. Eliam Majorem, P.L.C. Gymnasii Vratislaviensium Elisabetani Rectorem Meritissimum. Pia admodum placidaque morte, Anno Chr. M DC LXIX. XVI. Cal Augusti Rebus terrestribus exemtum... (Breslau, 1669); J.L. Flood, op. cit., vol. 3, p. 1235. 
incomplete by its very nature, will, nevertheless, bring a satisfying reconstruction of the past, so interestingly described by a musically educated Wrocław humanist.

Elias Maior filled with his notes successive volumes of calendars, designed by Valentin Hancke, and printed in $8^{\circ}$ format $(145 \times 90 \mathrm{~mm})$ by Wrocław printing office of Baumann. ${ }^{60}$ In these calendars, information was given by the editor about feasts, public gatherings and markets held in the consecutive days of the year, plus the astrological constellations and sometimes even weather forecasts resulting from them. But the majority of pages were left intentionally blank by the typographer for the user's notes. These pages were systematically completed by Elias Maior, writing on them rather brief and matter-of-fact accounts on almost daily basis (from 1 January 1640 until 16 June 1669). Usually, these are notes on events directly linked to the Elisabetanum's rector and meetings held in Wrocław schools, churches and houses; sometimes social and political events are referred to, there are also observations of nature and astronomy. However, the vast majority of the notes refers to Maior's public activity linked to didactic positions held by him in Wrocław: the town's school inspector and the rector of the St. Elizabeth's gymnasium.

As a rector, Maior was responsible, mainly, for the human resources and finances. Every quarter, he systematically noted down the rationes scholasticae owed to the school's teachers that he withdrew from the Wrocław municipal authorities' purse. These accounts show the social hierarchy of the gymnasium's tutors depending on the classes they taught: the most generously paid were the collegae primi ordinis - the tutors of the oldest class. At the same time, some of the teachers held musical positions, as, e.g., Johann Balthasar Cargius (Karg), who was a cantor at St. Elizabeth's church in $1643-1686,{ }^{61}$ or Daniel Sartorius (Schneider), who, most probably, taught, i.a., music at the

${ }^{60}$ Schreibkalender auffs das Jahr nach Chrifti Geburt... Mit Vermerckung etzlicher gewiffer Tage, an welchen das Fürten= oder Oberrecht, so wol das Königliche Mannrecht... Stadt=recht, Schöppenftube und Ferien bey Gerichten, die Groffe und Kleine Wollefchaar in der Kayfer= und Königlichen Stadt Breßlaw, pfleget gehalten zu werden. Allen Obrigkeiten, Doctorn, Cantzleyverwandten, Advocaten und Kauffleuten zu dienftlichem brauch fonderlich zugerichtet... Out of the 30 annual calendars written by Maior, up to our time have survived 22, kept today in the University Library in Wrocław (BUWr, Oddział Rękopisów, sign. R 2339 - R 2369).

${ }^{61}$ R 2347, fol. 24rec. [13 Feb. 1648]; R. Starke, "Kantoren und Organisten der St. Elisabethkirche zu Breslau," Monatshefte für Musikgeschichte 35, no. 3 (1903), pp. $41-48$. 
Elisabetanum. ${ }^{62}$ According to Maior's notes, results of the music teaching were used not only at school but also in church. ${ }^{63}$ The practice of combining teaching and church positions was possible thanks to the institutional and personal links between the parish and the school attached to it. ${ }^{64}$ Besides, this phenomenon is documented by the consecutive Schulordnungen of St. Elizabeth's gymnasium: after all, musicians for the ensemble of Chorknaben, singing at St. Elizabeth's church, were recruited from among its pupils.

In turn, the professional ensemble of the choralists (Choralisten) consisted of distinguished pupils of the gymnasium's older classes, who also acted as trainee teachers at school. ${ }^{65}$ Due to allowances granted to its members from the town's budget, their supervisor was the town's school inspector. He was responsible for the ensemble headcount: he hired new members, ${ }^{66}$ appointed the superiors (called the signators), paid compensations to the deceased choralists' families, ${ }^{67}$ imposed disciplinary measures, e.g., a several-hour solitary confinement (for brawls, thefts and drunken bouts). ${ }^{68}$ Choralists, who took music commissions without the supervisor's consent in other churches in town and neglecting their responsibilities in the home parish, were facing the same punishment. ${ }^{69}$ Moreover, Elias Maior

${ }^{62}$ R 2343, fol. 59rec. [14 Dec. 1644]; R 2347, fol. 142rec. [7 Oct. 1648]; R 2348, fol. 79rec. [7 June 1649]; R 2349, fol. 29rec. [23 Feb. 1650] etc. Cf. T. Jeż, "The Italian Music Collection of Daniel Sartorius from Breslau," in: Music Migration in the Early Modern Age: Centres and Peripheries - People, Works, Styles, Paths of Dissemination and Influence, ed. J. Guzy-Pasiak, A. Markuszewska (Warszawa, 2016), pp. 171-182.

${ }^{63}$ R 2342, fol. 65rec. [8 May 1643]; R 2348, fol. 102rec. [23 July 1649]; R 2349, fol. 98rec. [11 July 1650].

${ }^{64}$ Bauch, Geschichte des Breslauer Schulwesens, pp. 339-342.

65 Sass, op. cit., pp. 13-14, 30, 33-39.

66 To the St. Elizabeth's church ensemble of choralists, were taken by Elias Maior, i.a., Matthias Reichenavius - R 2342, fol. 22rec. [11 Feb. 1643], Daniel Hempelius - R 2345, fol. 169ver. [1 Dec. 1646], Balthasar Hell - R 2346, fol. 69ver. [15 May 1647], Christianus Agricola - R 2347, fol. 104rec. [24 July 1648], David Buchs - R 2348, fol. 67ver. [15 May 1649] and Martinus Reichel - R 2366, fol. 176ver. [15 Dec. 1667].

${ }^{67} \mathrm{R}$ 2357, fol. 82rec. [9 June 1658].

${ }^{68}$ Daniel Thomas - R 2343, fol. 62ver. [7 Dec. 1644]; Matthias Rechenavius R 2344, fol. 135rec. [25 Sept. 1645]; Nicolaus Maul - R 2345, fol. 122ver. [29 Aug. 1646]; Christoph Stollius - R 2357, fol. 163ver. [19 Nov. 1658]; Sigmundus Arnoldus - R 2358, fol. 4ver. [9 Jan. 1659].

${ }^{69}$ R 2347, fol. 141 rec. [5 Oct. 1648]: "N. Agricola Choralis, quo heri in aede Dorothea ubi festum Francisci celebrabatur. Musicam adjuvent et officium suum 
was obliged to draw disciplinary consequences to the gymnasium's younger pupils, whose noisy behaviour was frequently complained about by Wrocław burghers. ${ }^{70}$

Another duty of the Elisabetanum's rector was participating in school exams that took place at every gymnasium's class twice a year: at the turn of April and May and in mid-October. ${ }^{71}$ The pupils from the examined classes performed before the rector Latin declamations, with texts drawn from Horace's odes, Virgil's eclogues, Terence's comedies and Erasmus's colloquies. ${ }^{72}$ The performances were probably accompanied by music. The latter is suggested by the frequent presence, during the exams, of such teachers as Johann Balthasar Cargius or Daniel Sartorius, recorded by Maior. ${ }^{73}$ Which is proved by the above-mentioned 1643 Schulordnung, in which not only the length and frequency of the actus scholastici in Wrocław gymnasia was set, but also the method of funding ex publico the expenses on music was established, which were incurred on the occasion of staging these spectacles. ${ }^{74}$ The presence of music in the performances is also indicated by Maior's notes, in which he mentions certain musical works being woven into the script of spectacles, ${ }^{75}$ furnishing them with instrumental music, ${ }^{76}$ especially when it was required by the contents of the spectacle. ${ }^{77}$

The dynamic development of school theatre in Wrocław was also stimulated by the rivalry with the Jesuit school drama, which, from

in choro Elisabetano neglexerunt, jussu Dn. D An. Weberi, carceri scholastici, includitur."

${ }^{70}$ Hippe, op. cit., p. 168.

${ }^{71}$ Noack, op. cit., pp. 231-235.

${ }^{72}$ R 2348, fol. 145ver. [20 Oct. 1649]; R 2350, fol. 60rec. [26 April 1651]; R 2354, fol. 51ver. [13 April 1655]; R 2354, fol. 154rec. [4 Nov. 1655]; R 2355, fol. 63ver. [3 May 1656].

${ }^{73}$ E.g., R 2342, fol. 143ver. [14 Oct. 1643]; R 2343, fol. 33ver. [13 Oct. 1644]; R 2354, fol. 142ver. [12 Oct. 1655].

${ }^{74}$ Hippe, op. cit., pp. 176-177.

75 R 2343, fol. 63rec. [8 Dec. 1644]: “Actus a me institutus, habetur [- - ] Beati Dn Apellis Cantilena, Weiche Mars etc. tota sed per partes tres, Germanice decantata, Latini autem a duobus pueris recitata est."

${ }^{76} \mathrm{R}$ 2339, fol. 38rec. [13 March 1640]: "A prandio Actus scholasticus [- habitus est [- ] Musica sonuit omnio instrumentalis, citra humanam vocem."

77 R 2355, fol. 130ver. [14 Sept. 1656]: “Actus pomposis a Kleinwechter institutus, De Musica, habetur. Adhibita sunt Instrumenta Musica pleraque omnia." 
the 1640 s, flourished in the city. ${ }^{78}$ Elias Maior was even present at some of the first performances, organised by the Jesuits at the Wrocław Castle and St. Matthias's monastery, ${ }^{79}$ however, despite the Jesuits' repeated invitations, he did not attend any further. He also did not allow his pupils to attend them, ${ }^{80}$ as some after such spectacles converted to Catholicism... ${ }^{81}$ However, the escalating confessional conflict in the city did not prevent the mutual inspiration of the two milieux, both for the subject-matter used in spectacles and for the musical setting accompanying them. ${ }^{82}$ It concerned not only the classical school drama, but also the Passion spectacles staged by both confessions; it is known that actus passionales staged on Good Friday by St. Mary Magdalene's gymnasium enjoyed every year the presence of the Elisabetanum's rector. ${ }^{83}$

Apart from school and religious spectacles, the Wrocław Protestant gymnasia, at Maior's times, were also places that cultivated German-language theatre. But, even if we consider that the choice of German as a main medium for a school theatre was an escape from the rivalry with the Jesuits in Latin drama, it brought exceptionally good results for Wrocław Protestants, which were even emulated later by their confessional rivals... It were the gymnasia managed by Elias Maior that premiered spectacles by Martin Opitz (Judith; staged with music by Mattheus Apelles von Löwenstern [Matthäus Apelt]), Andreas Gryphius (Greif; Cardenio und Celinde, Felicitas, Papinianus) or Daniel Caspar von Lohenstein (Agrippina, Cleopatra, Epicharis, Sophonisbe) - authors that formed the canon of Modern German drama. ${ }^{84}$ The musical layer of these masterpieces is confirmed by information from the preserved summaries of theatre spectacles,

${ }^{78}$ Noack, op. cit., pp. 236-242; T. Jeż, Kultura muzyczna jezuitów na Śląsku i ziemi ktodzkiej (1581-1776) (Warszawa, 2013), pp. 312-378.

${ }^{79}$ R 2339, fol. 139ver. [2 Oct. 1640]; R 2342, fol. 139ver. [6 Oct. 1643].

${ }^{80}$ Hippe, op. cit., p. 180.

${ }^{81}$ R.J. Alexander, "Zum Jesuitentheater in Schlesien: Eine Übersicht," in: Funde und Befunde zur schlesischen Theatergeschichte, I. (Dortmund, 1983), p. 56.

82 J. Budzyński, Dramat i teatr szkolny na Ślasku (XVI-XVIII wiek) (Katowice, 1996), p. 25.

${ }^{83}$ R 2344, fol. 53rec. [14 April 1645]; R 2346, fol. 56ver. [19 April 1647]; R 2348, fol. 47 [2 April 1649] etc.

${ }^{84}$ Garber, op. cit., pp. 322-338; Das Breslauer Schultheater im 17. und 18. Jahrhundert: Einladungsschriften zu den Schulactus und Szenare zu den Aufführungen förmlicher Comödien an den protestantischen Gymnasien, ed. K. Gajek (Tübingen, 1994). 
staged by Maior, ${ }^{85}$ and by references in his diaries. ${ }^{86}$ Remarks on these spectacles are, unfortunately, of rather vague nature, maybe because he knew these plays even before they were performed: after all, as the school inspector he evaluated them as suitable for the gymnasia stages in Wrocław.

An important place of Elias Maior's activity was the St. Elizabeth's Church adjacent to the gymnasium. We owe numerous annotations in his diaries on music life of this sanctuary not only to the rector's piety, but also to the above-mentioned institutional relations, linking the school to the church dedicated to the same patron saint. In Maior's calendars, each year was started with information on strena musica, distributed (probably by the rector himself) in the first days of January to the musicians of the St. Elizabeth's Church: the cantor, signator and his deputy (subsignator), choralists and descantists not mentioned by name. Maior's inventories supplement the presently known personal records of Wrocław Parish Church musical ensemble with a lot of new data. ${ }^{87} \mathrm{We}$ cite them below in a table.

The above-mentioned musicians were responsible for a musical setting of the liturgy in the St. Elizabeth's Church and its filial St. Barbara's Church. In his notes, Elias Maior recorded his presence at the most important services in these churches, e.g. on Maundy Thursday, when the "sacrae synaxis" liturgy was adorned by "musica harmonica in choro, vocalis et instrumentalis". ${ }^{88}$ Usually, the performances were conducted by a cantor, Johann Balthasar Cargius (Karcken), ${ }^{89}$ and in his absence - Caspar Seifert, a signator. ${ }^{90}$ Maior, naturally, frequented the church services more often; in so doing, he used to make summaries of sermons preached by pastors, especially Johannes Acoluthus (Acoluth; 1628-1689), his former pupil at the Elisabetanum,

${ }^{85}$ Que res nobis, omnibusque Crucifixum Dominum amantibus, profpere eveniat! Veram Vitem Ejusque; Proprietates \& Folia in Pafionali Gymnafii Vratislavienfis Elifabetani actûu A. D. IV. Calend. Aprileis, CID IDC XLII. Pie contemplanda indicit M. Elias Major Rector (Breslæ, 1642; copy Berlin, sign. Ah 16124/20). There is a remark in the programme of this spectacle: "Ex Germanica quidem cantione, Da Jesus an dem Creutze stund, Græco carmine."

${ }^{86}$ Hippe, op. cit., p. 178.

${ }^{87}$ Cf. T. Jeż, “Z przeszłości muzycznej wrocławskiego kościoła św. Elżbiety w czasach baroku," Muzyka. Kwartalnik Instytutu Sztuki Polskiej Akademii Nauk 52, no. 4 (2007), pp. 83-111.

${ }^{88}$ R 2368, fol. 56rec. [18 April 1669].

${ }^{89}$ R 2357, fol. 56rec. [28 April 1658].

${ }^{90}$ R 2342, fol. 47rec. [2 April 1643]; R 2354, fol. 42rec. [25 March 1655]. 


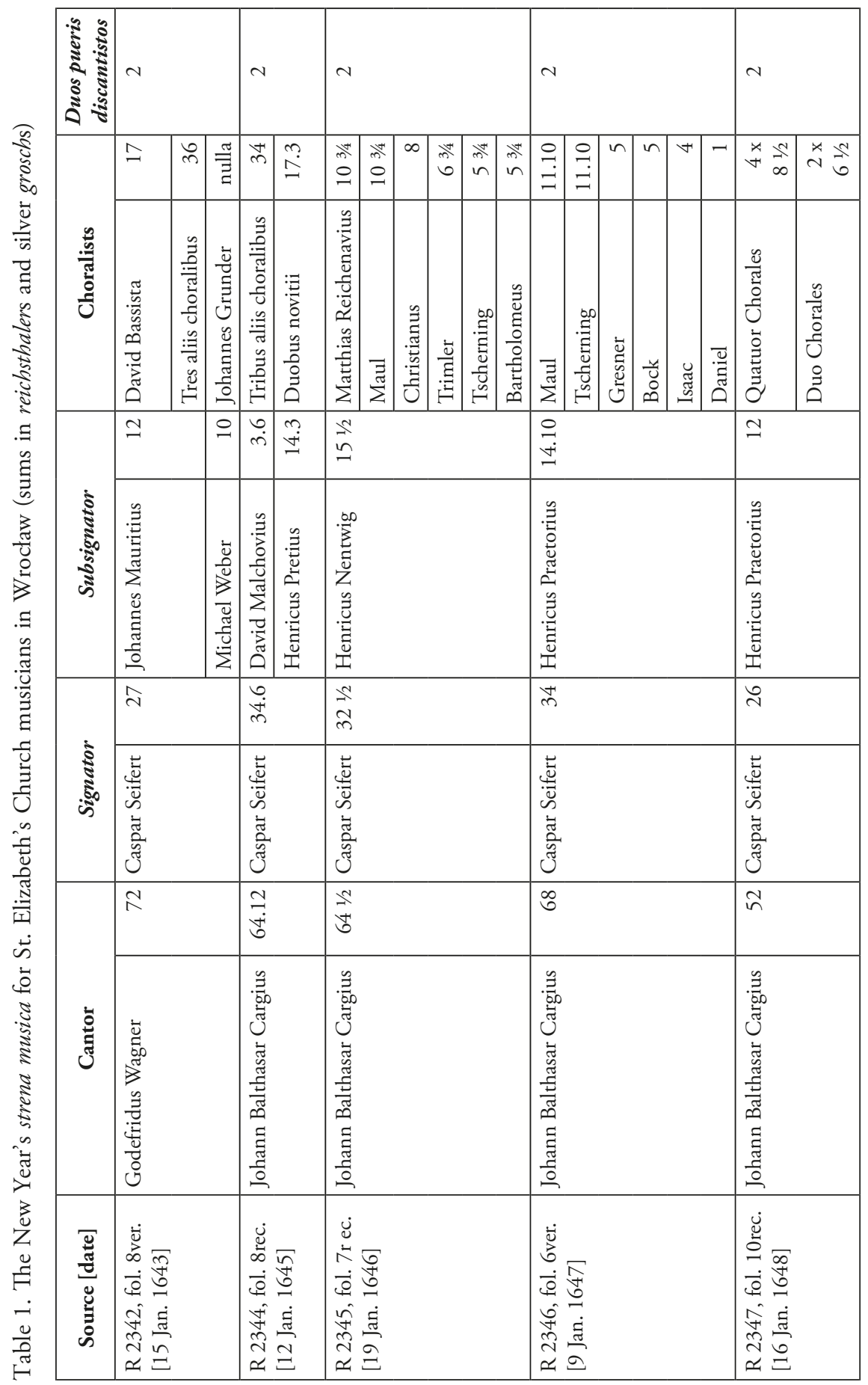




\begin{tabular}{|c|c|c|c|c|c|c|c|c|c|c|c|c|c|c|c|c|c|}
\hline 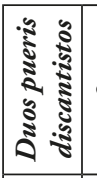 & \multicolumn{2}{|l|}{ N } & \multicolumn{3}{|l|}{$N$} & \multicolumn{4}{|l|}{$\sim$} & \multicolumn{3}{|l|}{1} & \multicolumn{3}{|l|}{1} & \multicolumn{2}{|l|}{1} \\
\hline \multirow[b]{2}{*}{$\begin{array}{l}\frac{5}{5} \\
\frac{5}{\pi} \\
\frac{\pi}{0}\end{array}$} & r & & $\hat{\imath}$ & \begin{tabular}{c|c} 
& $v$
\end{tabular} & $n$ & $\underset{\infty}{*} \underset{\infty}{n} \underset{\infty}{n}$ & $n$ & + & \begin{tabular}{l|l}
$\stackrel{\sim}{\rightleftharpoons}$ & -
\end{tabular} & \begin{tabular}{cc|}
$x$ & $\stackrel{0}{m}$ \\
$m$ & \multirow{\forall}{*}{}
\end{tabular} & \begin{tabular}{l|l}
\multirow{2}{*}{} \\
$i$ \\
in
\end{tabular} & 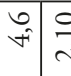 & 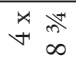 & \begin{tabular}{l|}
$\vec{*}+$ \\
$\vec{v}$
\end{tabular} & - & $\stackrel{\not}{\sim} \underset{\forall}{\vec{\forall}}$ & $\stackrel{N}{=}$ \\
\hline & 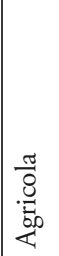 & & 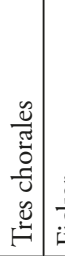 & 或 & 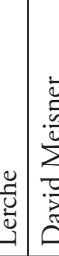 & 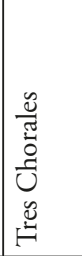 & $\mid$ & |: & 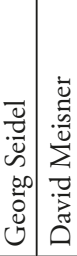 & 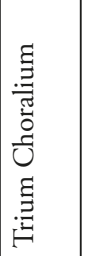 & $\mid \begin{array}{l}\dot{z} \\
z \\
z\end{array}$ & \begin{tabular}{l|l}
$Z$ & $Z$ \\
$z$ & $Z$
\end{tabular} & 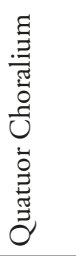 & 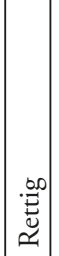 & 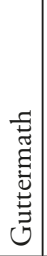 & 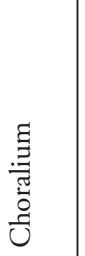 & 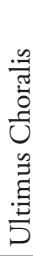 \\
\hline \multirow[b]{2}{*}{ 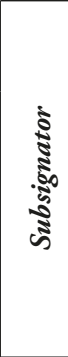 } & $\tilde{\varrho}$ & & $\exists$ & & & $\stackrel{0}{\leftrightarrows}$ & & & & $\stackrel{n}{\circ}$ & & & $\stackrel{m}{=}$ & & & $\stackrel{\sim}{0}$ & \\
\hline & 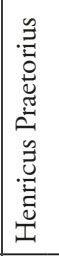 & & 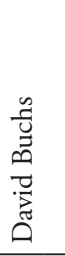 & & & 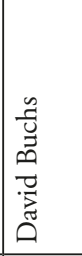 & & & & 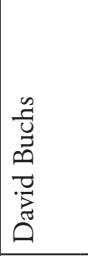 & & & 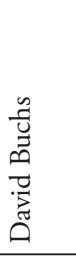 & & & 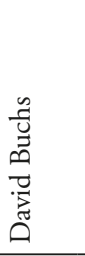 & \\
\hline \multirow[b]{2}{*}{ క్ } & $\begin{array}{l}\vec{\sim} \\
\ddot{\sim} \\
\vec{v}\end{array}$ & & $\hat{\lambda}$ & & & $\begin{array}{l}\sim \\
\stackrel{n}{0} \\
\text { i. }\end{array}$ & & & & $\begin{array}{l}\stackrel{0}{\sim} \\
\stackrel{\sim}{\sim}\end{array}$ & & & $\overrightarrow{\vec{d}}$ & & & $\vec{d}$ & \\
\hline & 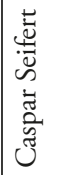 & & 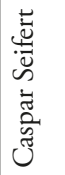 & & & 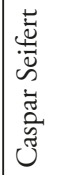 & & & & 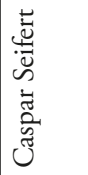 & & & 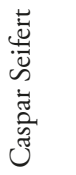 & & & 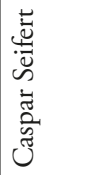 & \\
\hline \multirow[b]{2}{*}{ 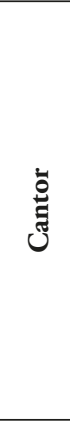 } & $\begin{array}{l}\text { I } \\
\stackrel{\forall}{\mid}\end{array}$ & $\sim$ & $\stackrel{\star r}{n}$ & & & $\tilde{n}$ & & & & 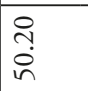 & & & $\begin{array}{l}\stackrel{N}{\sim} \\
\sim\end{array}$ & & & $\begin{array}{l}\vec{N} \\
\sim\end{array}$ & \\
\hline & 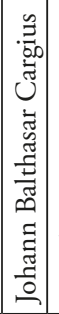 & 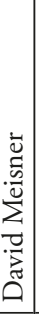 & 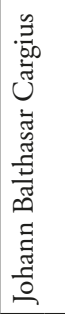 & & & 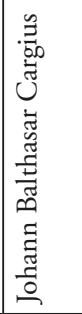 & & & & 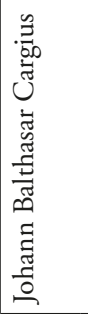 & & & 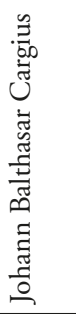 & & & 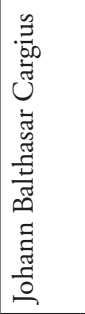 & \\
\hline 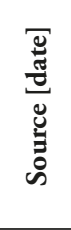 & 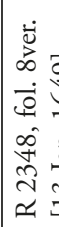 & & 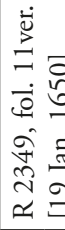 & & & 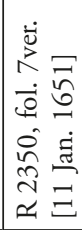 & & & & 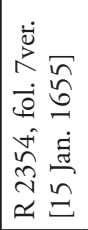 & & & 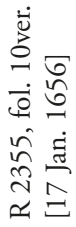 & & & 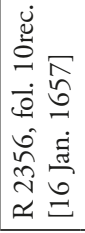 & \\
\hline
\end{tabular}




\begin{tabular}{|c|c|c|c|c|c|c|c|c|c|c|c|c|c|}
\hline \multicolumn{3}{|l|}{1} & 1 & \multicolumn{5}{|l|}{1} & \multicolumn{5}{|l|}{1} \\
\hline$\infty$ & $\forall$ & $N$ & $\stackrel{x}{\forall} \underset{\forall}{\stackrel{\sim}{+}}$ & $\sigma$ & $a$ & $a$ & tr & \begin{tabular}{|l|l}
+ & $m$
\end{tabular} & $\stackrel{+}{\forall}$ & $\stackrel{\leftrightarrow}{\forall}$ & 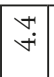 & $\stackrel{⿱ r}{\forall}$ & $\stackrel{+}{+4}$ \\
\hline 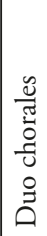 & 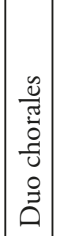 & 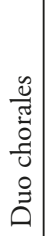 & 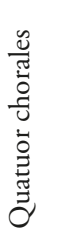 & 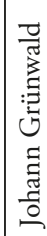 & 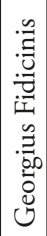 & 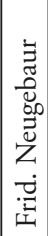 & 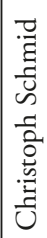 & 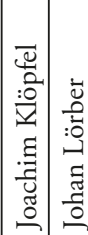 & 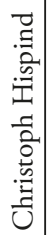 & 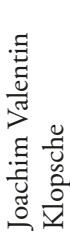 & 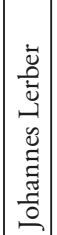 & 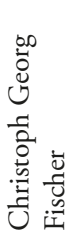 & 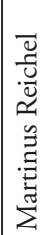 \\
\hline \multicolumn{3}{|c|}{$\stackrel{\overbrace{}}{\because}$} & 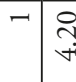 & \multicolumn{5}{|c|}{$\exists$} & \multicolumn{5}{|c|}{ ֻ1 } \\
\hline \multicolumn{3}{|c|}{ 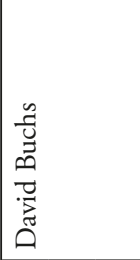 } & 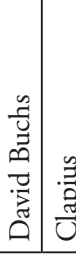 & \multicolumn{5}{|c|}{ 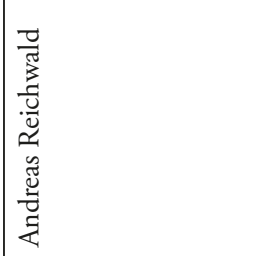 } & \multicolumn{5}{|l|}{ 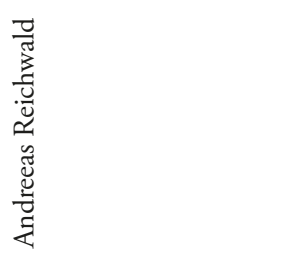 } \\
\hline \multicolumn{3}{|l|}{$\curvearrowleft$} & ㄱำ & \multicolumn{5}{|l|}{$\hat{\lambda}$} & \multicolumn{5}{|l|}{$\underset{\sim}{\stackrel{\sim}{\sim}}$} \\
\hline \multicolumn{3}{|c|}{ 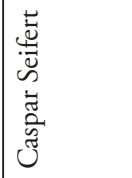 } & 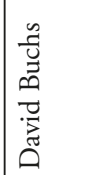 & \multicolumn{5}{|c|}{ 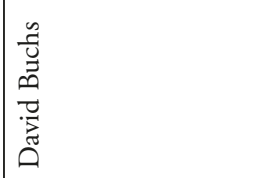 } & \multicolumn{5}{|l|}{ 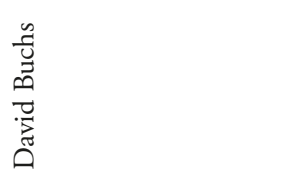 } \\
\hline \multicolumn{3}{|l|}{ 요 } & ก & \multicolumn{5}{|l|}{$\stackrel{\sim}{n}$} & \multicolumn{5}{|l|}{$\stackrel{\uplus}{\stackrel{\leftrightarrow}{*}}$} \\
\hline \multicolumn{3}{|c|}{ 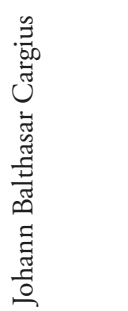 } & 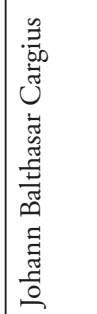 & \multicolumn{5}{|c|}{ 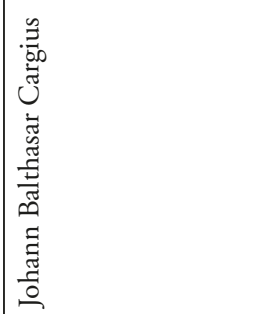 } & \multicolumn{5}{|l|}{ 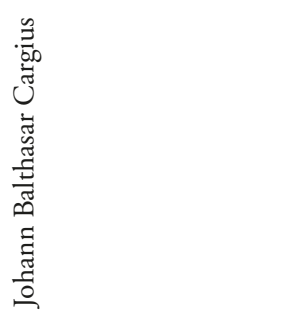 } \\
\hline \multicolumn{3}{|c|}{ 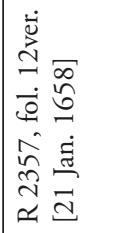 } & 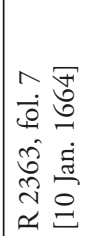 & \multicolumn{5}{|c|}{ 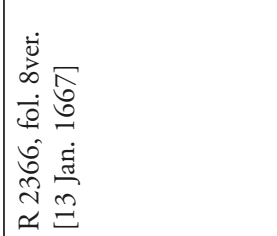 } & \multicolumn{5}{|c|}{ 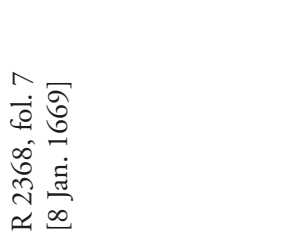 } \\
\hline
\end{tabular}


and later - his successor as Wrocław school inspector. ${ }^{91}$ Before this well-known author of hymns and editor of Doskonaty kancjonat polski (Brzeg 1673) was appointed St. Elizabeth's Church ecclesiastic, Maior noted down in his diary the titles of hymns sung in church before sermons, such as: Verleih uns die Zeiten gut, ${ }^{92}$ Christ der uns selig macht, ${ }^{33}$ Du Friedensfürst, Herr Jesu Christ ${ }^{94}$ or Nun last uns Gott der Herre. ${ }^{95}$ In one case the Wrocław rector mentioned a composer who arranged the choral tune; ${ }^{96}$ while in other he put in a calendar a score of a hymn sung instead of the usual Wenn wir in höchsten Nöten sein.

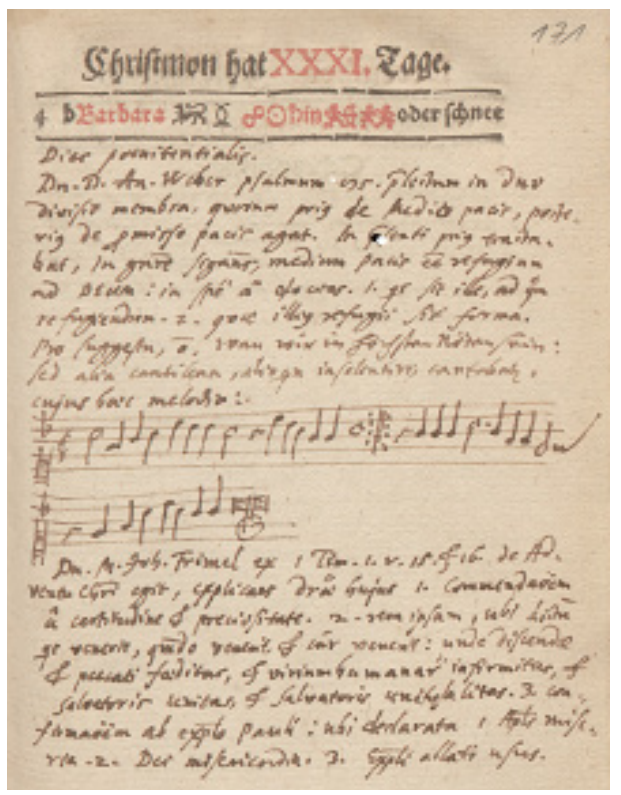

Fig. 2. Wrocław, Biblioteka Uniwersytecka, Oddział Rękopisów, R 2347, fol. 171 rec. [4 Dec. 1648]

${ }^{91}$ R 2363, fol. 52ver. [11 April 1664]; R 2363, fol. 113rec. [10 Aug. 1664]; R 2363, fol. 157ver. [7 Nov. 1664] etc. Cf. A. Rombowski, "Wydawcy Wielkiego Kancjonału Wrocławskiego z roku 1673,” Pamiętnik Literacki 45, no. 3 (1954), pp. 212-234.

92 R 2345, fol. 128rec. [9 Sept. 1646].

${ }^{3}$ R 2346, fol. 48rec. [3 April 1647].

${ }^{94} \mathrm{R}$ 2347, fol. 125ver. [4 Sept. 1648].

95 R 2354, fol. 89rec. [27 June 1655].

${ }^{96}$ R 2346, fol. 120ver. [25 Aug. 1647]: "Ultima cantilena fuit Verleih und Frieden gnädeglich \&c. utiquidem numeris Musicis accomodavit Hammerschmidius: ubi, Gib unserem fürsten, und aller Obrigkeit, canebatur." 
Music accompanied also some exceptional local ceremonies, such as the inauguration to the office of ecclesiastic in St. Elizabeth's Church ${ }^{97}$ of Johannes Acoluth or his predecessor - Ananias Weber. ${ }^{98}$ In both cases musical ensembles were conducted by cantor Cargius; but it happened sometimes that a musical setting of such ceremonies was led by the organist with accompanying musicians. ${ }^{99}$ Elias Maior took also part in funeral services at St. Elizabeth's, e.g., for Gottfried Wagner, a cantor of this church, ${ }^{100}$ Christian Sagittarius, a signator of St. Mary Magdalene's Church, ${ }^{101}$ Mattheus Apelles von Löwenstern, a Wrocław composer ${ }^{102}$, or Caspar Seifert, a signator of St. Elizabeth's Church (his funeral was accompanied by an exceptionally rich musical setting). ${ }^{103}$ Particularly solemn music - obviously of completely different expression - also enhanced coronations of emperors ${ }^{104}$ and the peaces declared by them, which were celebrated in Wrocław and rejoiced at by the hymn Te Deum laudamus, sung in churches and by vocal and instrumental music that sounded from the town's towers. ${ }^{105}$ Slightly less noisily, although equally solemn, were celebrations of the beginning of the school year; on this occasion, a service was accompanied by musica harmonica and the grand organ. ${ }^{106}$

In his diaries, Elias Maior reveals also quite a lot of information about his private life and a place of music in it. Weddings, celebrated at homes of his collaborators and friends: Johann Balthasar

${ }^{97}$ R 2366, fol. 75rec. [26 May 1667]: "Musica in choro, omnes alia in organo maiore, sonuit."

${ }^{98}$ R 2342, fol. 64ver. [7 May 1643]: "Sonuit musica in choro Harmonica, instituente Dn Joh. Balth. Cargio Cantore."

${ }^{99}$ R 2340, fol. 153rec. [31 Oct. 1641]: "Introductoria a Dn. M. Johann Fechnero habita. Adfuere propter ceteros virgulares, ipsi senatores decem. Musicam adornavit Dn. Ambrosius Profius, cui \& eius Adjuvantibus Gravitate trium Infirmicos ingalium datum."

${ }^{100}$ R 2342, fol. 12ver. [23 Jan. 1643]; R 2342, fol. 14ver. [27 Jan. 1643].

${ }^{101}$ R 2347, fol. 10ver. [17 Jan. 1648].

102 R 2347, fol. 60rec. [26 April 1648].

${ }^{103}$ R 2357, fol. 84rec. [13 June 1658]: "In turri curiali tubae \& tympana sonuere. In turribus Elisabetana \& Magdalanea, Musica instrumentalis \& vocalis sonitu."

${ }_{104}$ R 2355, fol. 139rec. [1 Oct. 1656]; R 2356, fol. 29rec. [25 Feb. 1657]; R 2357, fol. 112ver. [11 Aug. 1658].

${ }^{105}$ R 2346, fol. 93ver. [2 July 1647]; R 2347, fol. 108rec. [25 Oct. 1648]; R 2349, fol. 104ver. [24 July 1650]; R 2363, fol. 176 [14 Dec. 1664].

106 R 2339, fol. 140rec. [3 Oct. 1640]; R 2341, fol. 140rec. [3 Oct. 1642]; R 2356, fol. 140rec. [5 Oct. 1657]; R 2357, fol. 140ver. [4 Oct. 1658]; R 2358, fol. 138rec. [3 Oct. 1659]; R 2366, fol. 138rec. [29 Sept. 1667]. 
Cargius, ${ }^{107}$ Andreas Eccard, ${ }^{108}$ Johannes Gebhard ${ }^{109}$, and Ambrosius Profe $^{110}$ could not have done without it. Maior mentions music far more often on such occasions, as his own name day, celebrated on 20 July or a couple of days later, usually with his friends, "cum vino et carminibus". ${ }^{111} \mathrm{He}$ did not mean just songs, but perhaps a more sophisticated repertoire, as he noted a few times: "sonuit vocalis $\&$ instrumentalis musica", ${ }^{112}$ only once described as "mediocris". ${ }^{113}$ Maior's guests included the Elisabetanum's teachers, mentioned by name, Ambrosius Profe, the organist and his children, together with their spouses. ${ }^{114}$ His gymnasium's pupils sometimes happened to be invited, who "musicam instrumentali \& vocali [- $]$ Nominalem diem honorare voleruent". ${ }^{115}$ Maior noted a couple of times that they performed a repertoire, composed especially for him and sometimes even printed on this occasion. ${ }^{116}$

Circumstances for music-making were also created on Ambrosius Profe's name day, who annually, on 4 April, invited his brother-in-law at his place for dinner or supper. When there were more guests, Maior noted the music party and young people dancing, ${ }^{117}$ however, he mentioned more often the wine drunk on this occasion ${ }^{118}$ and the consumed fish dishes ${ }^{119}$ and gingerbreads. ${ }^{120}$ The Elizabethan organist was Maior's close friend. In the diaries, most frequently, even several times a year, references to the meals with Profe appear. The mutual relations of both friends is also demonstrated by the "balneae domesticae", taken together ${ }^{121}$, or by Maior's practical help to Profe, after

107 R 2343, fol. 55ver. [29 Nov. 1644].

${ }^{108}$ R 2344, fol. 62rec. [2 May 1645].

109 R 2344, fol. 167rec. [28 Nov. 1645].

${ }^{110}$ R 2347, fol. 155ver. [3 Nov. 1648].

111 R 2339, fol. 102ver. [20 July 1640].

112 R 2339, fol. 103ver. [22 July 1640]; R 2342, fol. 100ver. [20 July 1643].

113 R 2344, fol. 101ver. [20 July 1645].

${ }^{114}$ R 2345, fol. 103ver. [22 July 1646]; R 2346, fol. 103ver. [22 July 1647]; R 2348, fol. 101ver. [22 July 1649] etc.

115 R 2355, fol. 102ver. [20 July 1656].

${ }_{116}$ R 2358, fol. 100rec. [20 July 1659]; R 2358, fol. 100ver. [20 July 1659].

117 R 2345, fol. 49rec. [4 April 1646].

118 R 2347, fol. 49rec. [4 April 1648]; R 2349, fol. 49rec. [3 April 1650]; R 2350, fol. 49rec. [4 April 1651] etc.

${ }^{119}$ R 2354, fol. 57rec. [4 April 1655]; R 2356, fol. 48 [4 April 1657].

${ }^{120}$ R 2344, fol. 48rec. [4 April 1645]: "Nominalem Dn. Ambr. Profii vino \& paucis tabellis panis melleopiperati celebratum."

${ }^{121}$ R 2342, fol. 46rec. [31 March 1643]; R 2342, fol. 89rec. [27 June 1643]; R 2347, fol. 171ver. [5 Dec. 1648] etc. 
his accident ${ }^{122}$, and by the Elizabethan rector's mediation in solving a rather embarrassing case, as the organist's daughter, Maria, was determined to marry Christoph Wildenhain, a Catholic. ${ }^{123}$ Maior probably did not have any big trouble with his own children, although we do not know why a "Casparus Citharedeus", employed as a violin teacher for his daughter Rosina, was fired just after two months... ${ }^{124}$

Sometimes, Maior discussed music with Profe, e.g., on the occasion of Profe's publication of a collection of church concertos in Leipzig. ${ }^{125}$ The Wrocław rector talked "de re Musica" with Cargius, ${ }^{126}$ whom he also met at common meals with music. ${ }^{127}$ Music might have been the subject of conversation at suppers with Acoluth, ${ }^{128}$ although Maior wrote about it only when he was a guest of another Wrocław hymn-writer, Mattheus Apelles von Löwenstern. ${ }^{129}$ During their last meeting at Apelles's house, there were "Musici, qui $\&$ voce $\&$ instrumentis musicis hanc carnivalem conversarem $\&$ piam $\&$ suavum reddidere". ${ }^{130}$ Among the invited guests, there was also a young Elisabetanum's teacher - Daniel Sartorius, described by Maior as "juvenus doctissimus and philologus eximus". ${ }^{131}$ He inherited Profe's vast collection of Italian printed music, used in the Elizabethan gymnasium's teaching practice. ${ }^{132}$ Other participants of home banquets with music included organists, known to Maior, i.a. employed at Wrocław St. Mary Magdalene's Church: Bernhard Beyer ${ }^{133}$, Tobias Zeutschner, ${ }^{134}$ and also

${ }^{122}$ R 2348, fol. 114rec. [16 Aug. 1649]; R 2348, fol. 114ver. [17 Aug. 1649]; R 2348, fol. 161ver. [21 Nov. 1649].

${ }^{123}$ R 2358 fol. 54rec. [18 April 1659]; R 2358, fol. 74ver. [29 May 1659]; R 2358, fol. 78ver. [6 June 1659]; R 2358, fol. 93ver. [6 July 1659].

${ }_{124}$ R 2344, fol. 3rec. [2 Jan. 1645]; R 2344, fol. 31rec. [1 March 1645].

${ }^{125}$ R 2340, fol. 25rec. [15 Feb. 1641]: "Dn. Ambrosius Profius mecum coenabat, collocutus quoddam mecum de Epta Dedicatoria Cantilenis quaebundam Harmonicis Lipisae edendis, promittendam.” It ment probably Erster Theil Geistlicher Concerten und Harmonien à 1. 2. 3. 4. 5. 6. 7. \&c Vocibus... zum öffentlichen Druck befördert durch Ambrosium Profium, Organisten zu St. Elisabeth in Bresslaw (Leipzig, 1641).

126 R 2342, fol. 53rec. [14 April 1643].

127 R 2347, fol. 118ver. [21 Aug. 1648].

${ }^{128}$ R 2363, fol. 137ver. [28 Sept. 1664]; R 2366, fol. 126rec. [5 Sept. 1667]; R 2368, fol. 5rec. [6 Jan. 1669].

${ }^{129}$ R 2342, fol. 107rec. [1 Aug. 1643].

${ }_{130} \mathrm{R}$ 2347, fol. 37rec. [11 March 1648].

131 R 2344, fol. 138rec. [1 Oct. 1645]; R 2346, fol. 150ver. [24 Oct. 1647].

132 Jeż, "The Italian Music Collection," p. 177.

${ }^{133}$ R 2344, fol. 161 [16 Nov. 1645]; R 2363, fol. 56rec. [18 April 1664].

${ }^{134}$ R 2348, fol. 61ver. [3 May 1649]; R 2354, fol. 168ver. [3 Dec. 1655]. 
Sigismund Franck of Neumarkt (Środa Śląska), ${ }^{135}$ Andreas Rauch of Liegnitz (Legnica) ${ }^{136}$, and Johannes Kessel of Oels (Oleśnica). ${ }^{137}$

References to music also appear in Maior's accounts of "recreationes in tabula oblonga", taking place in the circle of friends, in their suburban gardens, i.a., at August Vollgnad's. ${ }^{138}$ These merry convivia, with such guests as: Mattheus Appelles, Ambrosius Profe, Daniel Sartorius, were often adorned by music performed both by the party-makers and professionals invited on this occasion. ${ }^{139}$ Music could be heard during trips to the other bank of the Oder or Ohle, which Maior used to participate in together with Apelles's and Profe's families. They often used to end with banquets at suburban taverns. ${ }^{140}$ During one of them the Wrocław gymnasium's rector even recorded a tune played by a local fiddler:

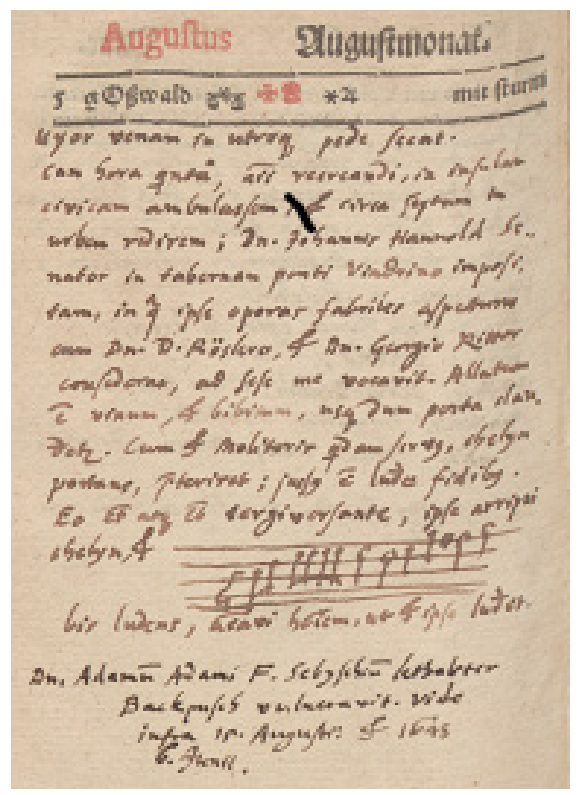

Fig. 3. Wrocław, Biblioteka Uniwersytecka, Oddział Rękopisów, R 2346, fol. 110ver. [5 Aug. 1647]

${ }^{135}$ R 2340, fol. 80ver. [6 June 1641].

136 R 2344, fol. 153ver. [1 Nov. 1645].

${ }_{137}$ R 2354, fol. 99 [17 July 1655]; R 2354, fol. 101rec. [21 July 1655].

138 R 2339, fol. 126ver. [6 Sept. 1640]; R 2339, fol. 130rec. [13 Sept. 1640]; R 2340, fol. 77rec. [30 May 1641] etc.

${ }_{139}$ R 2348, fol. 7rec. [10 Jan. 1649]; R 2345, fol. 92rec. [20 June 1646].

${ }_{140} \mathrm{R}$ 2344, fol. 86rec. [19 June 1645]. 
Teaching activity at the gymnasium, organisation of theatrical spectacles, active participation in liturgical life, meetings and conversations with friends, banquets in suburban gardens - all these forms of activity constitute the extremely vivid portrait of Elias Maior. From the Schreibkalenders, written by him, the figure of the polymath and humanist emerges: involved in perfecting of educational procedures, Latin teaching and enforcing school discipline, deep Passion devotion and joy of life experienced in the circle of acquaintances. All these manifestations of activity were linked to the sensitivity to beauty of music that harmoniously merged domains of "cultus externus and internus", public and private spheres, Art and Nature, work and leisure, and also searching for rhymes for epithalamia and wine drinking, even an "ultra mediocritatem" one. ${ }^{141}$ Maior's humanism, who was able to easily fit in the stage of his own school, the choir of his own

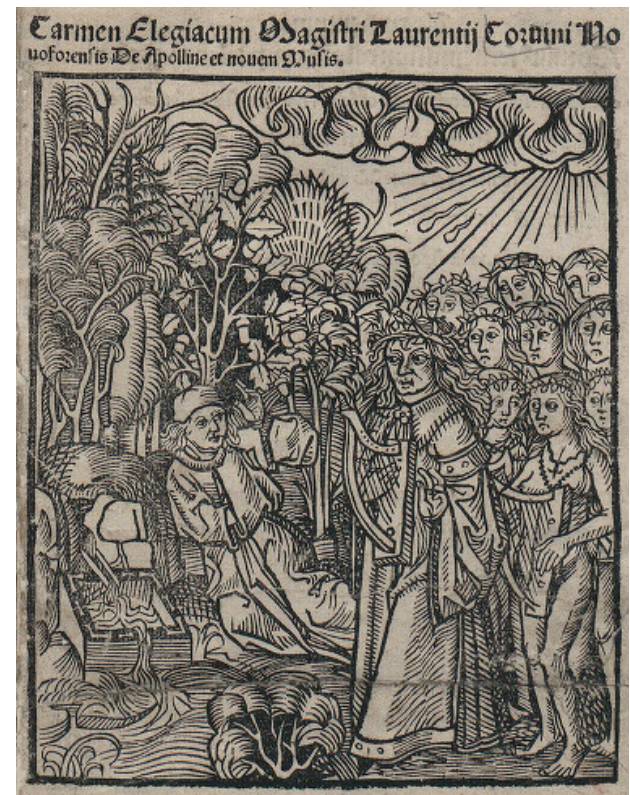

Fig. 4. Carmen elegiacum Magistri Laurentij

Coruini... De Apolline et nouem Musis (Breslau, 1503), Biblioteka Jagiellońska, St. Dr. Cim. 5151.

${ }^{141}$ R 2345, fol. Gver. [9 Jan. 1646]. 
parish, the town's council bench and the table at a suburban garden, could have been appreciated by both Erasmus and Melanchthon. It would also be praised by Laurentius Corvinus, who proceeding to the Oder banks after dinner, met there Apollo with all the nine Muses, the patrons of the Elisabetanum.

\section{Bibliography}

Absmeier Ch., "Szkoły a region: szkolnictwo śląskie wieku reformacji," in: Ślaska Republika Uczonych, vol. 3, ed. M. Hałub, A. Mańko-Matysiak (Wrocław, 2008), pp. 121-132

Alexander R.J., "Zum Jesuitentheater in Schlesien: Eine Übersicht," in: Funde und Befunde zur schlesischen Theatergeschichte, I. (Dortmund, 1983)

Arletius J.C., Historischer Entwurf von den Verdiensten der Evangelischen Gymnasiorum in Breslau um die deutsche Schaubühne (Breslau, 1762)

Bauch G., "Beiträge zur Literaturgeschichte des schlesischen Humanismus," Zeitschrift des Vereins für Geschichte und Altherthum Schlesiens 30 (1896), pp. 127-164

Bauch G., Geschichte des Breslauer Schulwesens in der Zeit der Reformation (Breslau, 1911; Codex diplomaticus Silesiae, vol. 26)

Bauch G., "Laurentius Corvinus, der Breslauer Stadtschreiber und Humanist," Zeitschrift des Vereins für Geschichte und Althertum Schlesiens 17 (1883), pp. 230-302

Budzyński J., Dramat i teatr szkolny na Ślasku (XVI-XVIII wiek) (Katowice, 1996)

Budzyński J., Paideia humanistyczna czyli wychowanie do kultury: studium z dziejów klasycznej edukacji w gimnazjach XVI-XVIII wieku (na przyktadzie Sląska) (Częstochowa, 2003)

Burbianka M., "Andrzej Winkler - drukarz wrocławski XVI wieku," Roczniki Biblioteczne 4 (1960), pp. 329-445, 636-638

Cunradus J.H., Silesia Togata, ed. C.Th. Schindlerus (Lignicii, 1706)

Das Breslauer Schultheater im 17. und 18. Jahrhundert: Einladungsschriften $z u$ den Schulactus und Szenare zu den Aufführungen förmlicher Comödien an den protestantischen Gymnasien, ed. K. Gajek (Tübingen, 1994)

Fleischer M.P., "Die Konkordienformel in Schlesien," Jahrbuch für schlesische Kirchengeschichte 58 (1979), pp. 50-83

Flood J.L., Poets Laureate in the Holy Roman Empire. A Bio-bibliographical Handbook, 4 vols. (Berlin, 2006)

Garber K., Das Alte Breslau. Kulturgeschichte einer geistigen Metropole (Köln, Weimar, and Wien, 2014) 
Hancke M., Vratislaviensis Eruditiones Propagatores: Id est, Vratislaviensium Scholarum Presides, Inspectores, Rectores, Professores, Praeceptores Tabulis Chronologicis comprehensi... (Leipzig, 1701)

Harasimowicz J., "Śląski luteranizm wieku Reformacji - próba charakterystyki," Ślaski Kwartalnik Historyczny Sobótka 39, no. 4 (1984), pp. 493 516

Hippe M., "Aus dem Tagebuche eines Breslauer Schulmannes im siebzehnten Jahrhundert," in: Breslauer Studien. Festschrift des Vereins für Geschichte und Althertum Schlesiens zum fünfundzwanzigjährigen Amtsjubiläum seines Vizepräses Hermann Markgraf (Breslau, 1901), pp. 159-192

Jeż T., "Stypendia wrocławskiej Rady Miejskiej jako instytucja kształcenia kadr muzycznych," in: Ślaska Republika Uczonych, vol. 3, ed. M. Hałub, A. Mańko-Matysiak (Wrocław, 2008), pp. 155-181

Jeż T., "The Italian Music Collection of Daniel Sartorius from Breslau," in: Music Migration in the Early Modern Age: Centres and Peripheries People, Works, Styles, Paths of Dissemination and Influence, ed. J. Guzy-Pasiak, A. Markuszewska (Warszawa, 2016), pp. 171-182

Jeż T., Kultura muzyczna jezuitów na Śląsku i ziemi ktodzkiej (1581-1776) (Warszawa, 2013), pp. 312-378

Jeż T., "Z przeszłości muzycznej wrocławskiego kościoła św. Elżbiety w czasach baroku," Muzyka. Kwartalnik Instytutu Sztuki Polskiej Akademii Nauk 52, no. 4 (2007), pp. 83-111

Konrad P., Die Einführung der Reformation in Breslau (Breslau, 1917)

McDonald G., "Laurentius Corvinus a renesansowe miasto Wrocław," in: Wroctaw literacki, ed. M. Kopij, W. Kunicki, T. Schulz (Wrocław, 2007), pp. 47-62

Philippi Melanchthonis opera quae supersunt omnia, ed. C.G. Bretschneider (Halle, 1834; Corpus Reformatorum, vol. 1)

Noack L., Christian Hoffmann von Hoffmannswaldau (1616-1679): Leben und Werk (Tübingen, 1999)

Rombowski A., "Wydawcy Wielkiego Kancjonału Wrocławskiego z roku 1673," Pamiętnik Literacki 45, no. 3 (1954), pp. 212-234

Sander H.-A., Beiträge zur Geschichte des Lutherischen Gottesdienstes und der Kirchenmusik in Breslau. Die lateinische Haupt- und Nebengottesdienste im 16. und 17. Jahrhundert (Breslau, 1937)

Sass J., Die kirchenmusikalischen Ämter und Einrichtungen an den drei evangelischen Haupt- und Pfarrkirchen der Stadt Breslau (Breslau, 1922)

Soffner J., Geschichte der Reformation in Schlesien (Breslau, 1886)

Starke R., "Ambrosius Profe," Monatshefte für Musikgeschichte 34, no. 11 (1902), pp. 189-196; 34, no. 12 (1902), pp. 199-215

Starke R., "Kantoren und Organisten der St. Elisabethkirche zu Breslau," Monatshefte für Musikgeschichte 35, no. 3 (1903), pp. 41-48 


\begin{abstract}
In late fifteenth century, the St. Elizabeth's school in Wrocław was already a key centre of Silesian humanism, i.a., thanks to Laurentius Corvinus and other alumni of the Cracow Academy. The subsequent generations of teaching staff of this institution studied in Wittenberg, i.a., at Philip Melanchthon's, who strongly influenced Wrocław's intellectual elite. The Reformation, introduced to the town's churches, was accompanied by an educational reform, which allowed, during Andreas Winkler's rectorate, in 1562, for the school to be granted the status of gymnasium. Humanist ideals guided the consecutive rectors of the Elisabetanum, i.a., Elias Maior (1631-1669), who significantly developed the tradition of theatrical spectacles staged there. Elias Maior's literary and educational oeuvre has an interesting interpretative background in his preserved Schreibkalenders, which Wrocław humanist filled with notes over several years of his rectorate. These notes constitute a unusually rich source, documenting the everyday life of the Elizabethan gymnasium's rector, lived both in publicis: at school, in the parish church and at the town's hall, and privatim: at friends' homes, gardens and taverns. Repeated references to music deserve special attention. It was performed on every above-mentioned occasion. The picture emerging from the notes reveals a unique description of musical life of the metropolis on the Oder, by an educated poeta lauretaus from Wrocław.
\end{abstract}

Tomasz Jeż studied musicology in Warsaw, Göttingen and Berlin. Having received his $\mathrm{PhD}$ (2002), he was employed as assistant professor at the Institute of Musicology, University of Warsaw. For the 2007/2008 academic year he received the postdoc scholarship of the Foundation for Polish Science at Rome. He is the author of three books and over sixty studies and articles on heuristic and spiritual contexts of the music culture. His scholarly interest focuses on the music culture of Silesia and the Polish-Lithuanian Commonwealth in the sixteenth-eighteenth centuries.

E-mail: tomasz.jez@uw.edu.pl

Trans. by Agnieszka Pospiszil

First published as: " $Z$ pamiętników muzykalnego humanisty. Schreibkalender Eliasa Maiora (1588-1669) jako źródło do historii kultury muzycznej Wrocławia," Odrodzenie i Reformacja w Polsce 61 (2017), pp. 165-193

The publication of this English translation has received additional funding from the Ministry of Science and Higher Education of the Republic of Poland 